\title{
Health condition of juvenile exotic carp Cyprinus carpio from various fish farms of Mymensingh area, Bangladesh
}

\author{
Ahmed $^{1}$ GU, Akter ${ }^{2}$ MN, Islam ${ }^{3}$ MR and Rahman ${ }^{1}$ KMM \\ ${ }^{1}$ Department of Aquaculture, Faculty of Fisheries, Bangladesh Agricultural University, Mymensingh-2202; \\ ${ }^{2}$ Department of Aquaculture, Faculty of Fisheries, Hajee Mohammad Danesh Science and Technology \\ University, Dinajpur; ${ }^{3}$ Department of Fisheries and Marine Science, Noakhali Science and Technology \\ University, Sonapur, 3802, Noakhali
}

[Received: November 24, Accepted: December 29, 2011]

\begin{abstract}
Clinical and histopathological studies were carried out with juvenile common carp (C. carpio) from a Government fish farm and a NGO fish farm in Mymensingh area for a period of 9 months from April 2005 to December 2005. Clinically red spots, scale loss, weak body, hemorrhage and subcutaneous lesion were noticed especially during November and December. A moderate pathological change in the investigated organs of all fishes were recorded in summer season (April-May), whereas in rainy season (June-July) pathological symptoms were significantly reduced which was again increased to some extent in the autumn season (August-September). However, marked pathological changes such as necrosis, protozoan cyst, bacterial colony, vacuum, melanomacrophase, hemorrhage, hypertrophy, hyperplasia and clubbing were recorded in all the investigated organs like skin, muscle, gill, liver and kidney in the months of October, November and December. Among the affected organs gills were more affected with the presence of numerous protozoan cysts followed by skin, liver and the less affected organ was the muscle. Clinically and histopathologically juvenile common carp of Government fish farm were more affected compare to NGO fish farm especially in colder moths of the year.
\end{abstract}

Key words: Disease, farming systems, health status

\section{INTRODUCTION}

Indian major carps occupied an important position among the cultivable fish species of Bangladesh. At present, not only major carps but also exotic carps are commonly cultured in our inland aquaculture because it is very delicious and content high nutrients. On the other hand, they are easy to culture because it is fast growing species with minimum mortality for having disease resistant capacity and ability to tolerate wide range of environmental conditions. However, natural population of these fishes are rapidly decreasing due to lack of scientific management, and draining of beels, marshes, ditches, and similar natural habitat for meeting up the excessive market demand and also for production of paddy and other agricultural crops ${ }^{[3]}$.

Disease has becomes a major problem in fish production both in culture system and wild condition in Bangladesh ${ }^{[13)}$. Extreme environmental changes may be fatal or cause stress to fish leading to secondary infections. Fish remaining in unfavourable environment which is loaded with innumerable agents like chemicals, pollutants, bacteria, virus, parasites, fungus etc., which are either individually or in combination, can inflict damage the body tissue or system producing disease of several kinds. Moreover the external and internal biology of these fishes are also altered by other physical, chemical and biological factors of the environment [12]. Common diseases of freshwater fishes of Bangladesh are ulcer type disease including epizootic ulcerative syndrome (EUS), septicemia disease, tail and fin rot, bacterial gill rot, dropsy, various types of fungal disease, protozoan diseases, parasitic diseases, nutritional diseases, tumors etc ${ }^{[5,6]}$. In most cases hemorrhages, septicemia, different kinds of lesions, gill damage etc. are common symptoms of the affected fish. Carps are also affected by a wide range of diseases and parasites. These are dermatomycosis, saprolegniasis, dropsy, fish pox or epidermal epithelioma, branchiomycosis, dactylogyrosis, furanculosis, columnaris, tail and fin rot, bacterial gill disease, bacterial kidney disease, white spot disease, tricodiniasis, myxosporidiasis, argulosis etc. In fish, the most obvious external clinical signs are inflammation, erythemia and hemorrhage of fins, skin or head, frayed or eroded fins, hemorrhaged opaque eye, open necrotic and ulcerative lesions at any location on the body, lepidorthosis of scales, and excessive mucus production. A total lack of mucus, edema, an enlarged abdomen, presence of yellow, white or black spots on the skin, prolapsed anus, and exophthalmia are all clinical sings of fish disease ${ }^{[11] .}$ The clinical signs, combined with parasitic investigation and histopathology may very helpful in diagnosing fish disease, which has been widely used throughout the world. In Bangladesh limited histopathological studies have been done on carp 
Table l. Clinical observation of investigated species in different months from both the farms

\begin{tabular}{|c|c|c|c|c|c|c|c|c|c|}
\hline $\begin{array}{l}\stackrel{\text { Months }}{\longrightarrow} \\
\stackrel{\text { Farms }}{\longrightarrow}\end{array}$ & April & May & June & July & August & September & October & November & December \\
\hline $\begin{array}{l}\text { Govt. Fish } \\
\text { Farm }\end{array}$ & $\mathrm{HA}$ & $\mathrm{HA}$ & $\overline{\mathrm{AN}}$ & $\overline{\mathrm{AN}}$ & $\begin{array}{l}\text { RS in 'c' } \\
\text { region }\end{array}$ & $\begin{array}{l}\text { AH \& gill } \\
\text { discoloration }\end{array}$ & $\overline{\mathrm{AN}}$ & $\begin{array}{l}\text { RS, SL \& } \\
\text { subcutaneo } \\
\text { us lesion }\end{array}$ & $\begin{array}{l}\text { Red spot in } \\
\text { 'c' region } \\
\& \text { weak } \\
\text { body. }\end{array}$ \\
\hline $\begin{array}{l}\text { NGO Fish } \\
\text { Farm }\end{array}$ & $\mathrm{HA}$ & $\mathrm{HA}$ & $\mathrm{HA}$ & $\begin{array}{l}\text { RSin } \\
\text { 'dv' }\end{array}$ & $\begin{array}{l}\text { SL in 'dv' } \\
\text { region \& weak } \\
\text { body }\end{array}$ & AN & AN & $\begin{array}{l}\text { Loss of 'cf', } \\
\text { weak body }\end{array}$ & $\begin{array}{l}\text { Ill health, } \\
\text { RS \& SL }\end{array}$ \\
\hline
\end{tabular}

*All abbreviations in this table are explained as follows

$\mathrm{AN}=$ almostnomal, HA=healthy appearance, $\mathrm{RS}=$ rough $\mathrm{skin}, \mathrm{SL}=\mathrm{Scale}$ loss, $\mathrm{c}=$ caudal, cf=caudal fin, dv=dorsoventral, gd=gill discoloration, $\mathrm{h}=$ hemorrhage, $\mathrm{v}=$ ventral.

Table 2. Histopathology of different organs of C. carpio from both the farms in different months

\begin{tabular}{|c|c|c|c|c|c|}
\hline $\begin{array}{l}\text { Seasons } \\
\text { Farms }\end{array}$ & $\begin{array}{l}\text { Seasons } \\
\text { (Months) } \\
\text { Organs }\end{array}$ & $\begin{array}{l}\text { Summar } \\
\text { (April- } \\
\text { May) }\end{array}$ & $\begin{array}{c}\text { Rainy } \\
\text { (June-July-August) }\end{array}$ & $\begin{array}{c}\text { Autumn } \\
\text { (September-October) }\end{array}$ & $\begin{array}{c}\text { Winter } \\
\text { (November- } \\
\text { December) }\end{array}$ \\
\hline \multirow[t]{4}{*}{$\begin{array}{l}\text { Govt. Fish } \\
\text { Farm }\end{array}$} & $\begin{array}{l}\text { Skin \& } \\
\text { muscle }\end{array}$ & $\begin{array}{l}\text { Almost } \\
\text { normal }\end{array}$ & $\begin{array}{l}\text { "e \& 'd' lost, "v" } \\
\text { seen }\end{array}$ & $\begin{array}{l}\text { ruptured 'm", "d" } \\
\text { separated, "v' \& 'mm" } \\
\text { seen }\end{array}$ & $\begin{array}{l}\text { "e' lost, ruptured ' } m \text { " } \\
\& \text { 'v' present }\end{array}$ \\
\hline & Gill & Normal & $\begin{array}{l}\text { "sgl' missing, "cl", } \\
\& \text { 'n' seen }\end{array}$ & 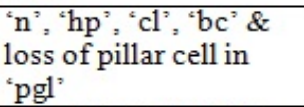 & $\begin{array}{l}\text { "n", "ht", "hp", "h' \& } \\
\text { "pc' seen in both 'gl' }\end{array}$ \\
\hline & Liver & Normal & $\begin{array}{l}{ }^{\circ} h^{\circ},{ }^{\prime} n^{\prime},{ }^{\prime} v^{\prime} \&{ }^{\prime} h " \\
\text { seen }\end{array}$ & ${ }_{\text {seen }} \mathrm{mm}^{\prime},{ }^{\prime} \mathrm{h}^{\circ},{ }^{\prime} \mathrm{n}^{\circ} \& \mathrm{c}^{\circ} \mathrm{v}$ & $\begin{array}{l}\text { "v', 'n'\& 'pk' cell } \\
\text { observed }\end{array}$ \\
\hline & Kidney & $\begin{array}{l}\text { Almost } \\
\text { normal }\end{array}$ & $\begin{array}{l}\text { swollen 'kt', 'fs' \& } \\
\text { "h' seen }\end{array}$ & $\begin{array}{l}\text { necrotic 'kt', 'v', 'fs", } \\
\text { 'h \& 'bc' seen }\end{array}$ & $\begin{array}{l}\text { 'h", "v', ,pk' nuclei } \\
\text { \& swollen 'kt' seen }\end{array}$ \\
\hline \multirow[t]{4}{*}{$\begin{array}{l}\text { NGO Fish } \\
\text { Farm }\end{array}$} & $\begin{array}{l}\text { Skin \& } \\
\text { muscle }\end{array}$ & $\begin{array}{l}\text { almost } \\
\text { normal }\end{array}$ & $\begin{array}{l}\text { "n', 'd' separated } \\
\text { \& ruptured 'm" } \\
\text { seen }\end{array}$ & $\begin{array}{l}\text { "v' \& ruptured ' } \mathrm{m} \text { ' } \\
\text { present }\end{array}$ & $\begin{array}{l}\text { "e'lost, 'd' splitted, } \\
\text { "v' \& 'mm' present }\end{array}$ \\
\hline & Gill & $\begin{array}{l}\text { More or } \\
\text { less normal }\end{array}$ & $\begin{array}{l}\text { "cl' \& "n' observed } \\
\text { in 'sgl" }\end{array}$ & $\begin{array}{l}\text { " } \mathrm{cl}^{\prime}, \text { loss of pillar cell } \\
\& \text { ' } h \text { ' seen }\end{array}$ & $\begin{array}{l}\text { "h", "hyp' \& "hyt" } \\
\text { observed in both "gl" }\end{array}$ \\
\hline & Liver & Normal & $\begin{array}{l}\text { ruptured 'hpt", 'pk" } \\
\text { nuclei, 'bc' \& 'h" } \\
\text { seen }\end{array}$ & $\begin{array}{l}\text { "v", 'bc' \& " } n \text { " } \\
\text { observed in liver cell }\end{array}$ & $\begin{array}{l}\text { 'pk' cell, 'v' \& 'h' } \\
\text { present }\end{array}$ \\
\hline & Kidney & Normal & $\begin{array}{l}\text { 'n", 'v', "h' \& } \\
\text { swollen 'kt' seen }\end{array}$ & $\begin{array}{l}\text { necrotic 'ht' cell, 'fs", } \\
\text { "v' \& swollen 'kt' } \\
\text { present }\end{array}$ & $\begin{array}{l}\text { large "v", 'n", 'p' \& } \\
\text { "h' observed }\end{array}$ \\
\hline
\end{tabular}

*All abbreviations in this table are explained as follows

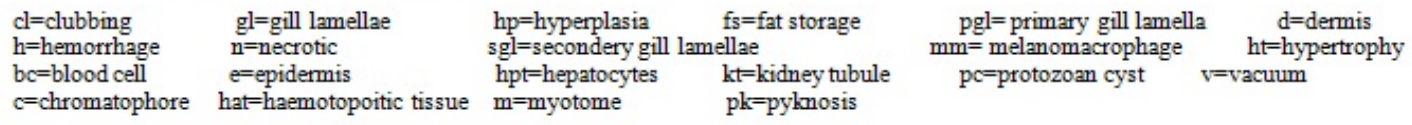

species. So the present work was undertaken for identifying the occurrence of diseases in C. carpio.

\section{MATERIALS AND METHODS}

The present study was conducted considering two fish farms in Mymensingh district, Bangladesh for a period of 9 months from April 2005 to December
2005. Farms were Government Fish Seed Multiplication Farm at Kajiakandi villege, under Fulpur Upazila $(25 \mathrm{~km}$ to east side from Mymensingh town) and the other was Society for Social Service (SSS) under NGO at Shahpur village under Fulpur Upazila (about $2 \mathrm{~km}$ to west side from Fulpur Upazila Office). Water quality parameters like $\mathrm{P}^{\mathrm{H}}$, dissolve oxygen, temperature, total hardness, 
conductivity and total dissolve solids were estimated during the experimental period at monthly intervals between 8.0 AM to 9.0 AM.
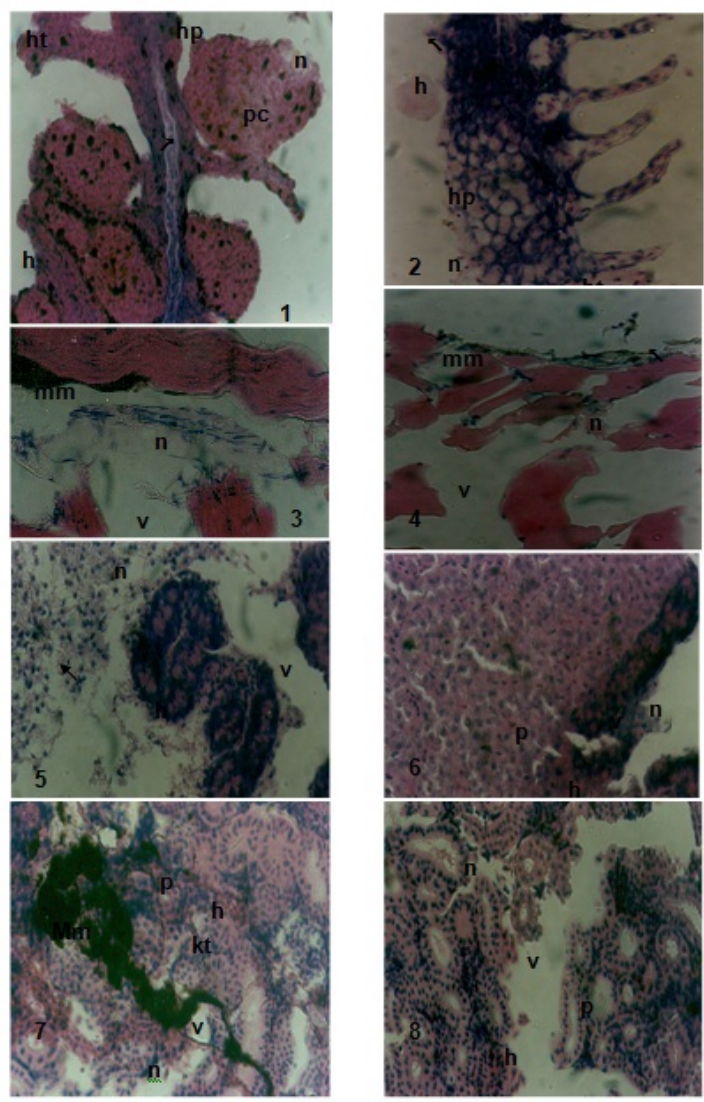

(Legends of figures, will go to opposite side page)

Figure 1. Section of gill of C. carpio collected from Government fish farm in December. Protozoan cysts (pc), necrosis (n), hypertrophy (ht), hyperplasia (hp), hemorrhagic (h) and loss of pillar cells $(\uparrow)$ were seen. $\mathrm{H} \& \mathrm{E} \times 532$.

Figure 2. Section of gill of $C$. carpio collected from NGO fish farm in December.Hypertrophy (ht), hyperplasia hp), haemorrhage (h), necrosis (n) and loss of Secondary gill lamellae (飞). H \& E × 532 .

Figure 3. Section of skin and muscle of $C$. carpio collected from Government fish farm in December. Epidermis lost $(\uparrow)$, necrotic myotomes (n), melanomacrophase $(\mathrm{mm})$ and vacuoles (v) were seen. $\mathrm{H} \& \mathrm{E} \times 532$.

Figure 4. Section of skin and muscle of C. carpio collected from NGO fish farm in December.

Epidermisotally and dermis partly lost ( $\mathbf{\nwarrow})$, vacuole (v) and melanomacrophage $(\mathrm{mm})$ in the myotomes were seen. $\mathrm{H} \& \mathrm{E} \times 532$.

Figure 5. Section of liver of $C$. carpio collected from Government fish farm in November \& December. Vacuoles (v), necrosis (n), hemorrhage (h) \& pyknotic cell (p) were seen. H \& E × 532 .
Figure 6. Section of liver of C. carpio collected from NGO fish farm in July and August. Necrotic hepatocytes (n), pyknotic nuclei (p), vacuum (v) and hemorrhage (h) were seen. H\& E $\times 532$.

Figure 7. Section of kidney of $C$. carpio collected from Government fish farm in December. Hemorrhage (h), necrosis (n), vacuole (v), pyknotic nuclei (p), melanomacrophage ( $\mathrm{mm})$ and swollen kidney tubules (kt) were seen. $\mathrm{H} \& \mathrm{E} \times 532$.

Figure 8. Section of kidney of $C$. carpio collected from NGO fish farm in November \& December. Large vacuole (v), necrosis (n), pyknosis (p) and hemorrhage (h) were seen. H \& E × 532 .

Standard procedures and methods were followed by using HACH'S kit (Model FF-1A). Sampling was carried out at monthly intervals. During each sampling, 6 fishes of $C$. carpio were collected from each farm with the help of seine net. Fish samples were transported to the Fish Disease Laboratory of the Faculty of Fisheries with plastic bags. The sampled fishes were examined just after taking out of the container to observe external symptoms and recorded any injury, infection and other abnormal conditions of fish body. Various organs such as skin and muscle, gills, liver and kidney were collected by a sharp scalpel and forceps, which were fixed in $10 \%$ neutral buffered formalin. Then the samples were placed in an automatic tissue processor for dehydration, clearing and infiltration (SHANDON, CITADEL 1000). The samples were then embedded, sectioned $(5 \mu \mathrm{m})$ and stained with Haematoxylin and Eosin. Then the sections were mounted with Canada balsam and covered by a cover slip and examined under a compound microscope (OLYMPUS). Photomicrographs were then taken by using a photomicroscope (OLYMPUS, Model CHS, Japan). Pathological observations were made from the slides and photographs. Clinical and pathological comparisons were made from the slides and photographs and compared among the months and between the farms.

\section{RESULTS AND DISCUSSION}

Among all the water quality parameters only water temperature become unfavourable for fish culture in December. The values of water temperature of Government and NGO fish farm were more or less similar. The highest value of water temperature of Government fish farm was recorded $31{ }^{0} \mathrm{C}$ in July and lowest $18{ }^{\circ} \mathrm{C}$ in December 2005.On the other hand, the highest value of water temperature of NGO fish farm was recorded $30{ }^{\circ} \mathrm{C}$ in June and lowest $19^{0}$ $\mathrm{C}$ in December 2005. ${ }^{[8]}$ described that, when water temperature was the lowest, the out break of disease was the highest. They also concluded that in low temperature fish immune system could not work strongly and eventually the fish would become more susceptible to disease. According to ${ }^{[16],}$ a sudden 
drop of temperature in water was supposed to be an important predisposing cause of disease outbreak. On the other hand, clinically $C$. carpio of both farms were in healthy appearance in the months of April, May, June and July and almost normal in September and October. The fishes were more affected during the months of winter (November and December). In NGO fish farm, clinically scale loss, weak body and red spot were observed in C. carpio in December (Table 1). Whereas, the fishes that were collected from Government fish farm showed clinical signs such as red spot, scale loss and weak body, hemorrhage, and subcutaneous lesion in November and December (Table 1). ${ }^{[15]}$ observed that in $N$. nandus rough skin and scale loss in October and November.

In NGO farm, both the primary and secondary gill lamellae were considerably less affected in comparison with the gills of species obtained from the Government fish farm. In NGO fish farm, hypertrophy, hyperplasia, hemorrhagic and necrotic gill lamellae were observed in November and December (Table 2, Figure. 2). But in Government fish farm, protozoan cysts were observed between the primary and secondary gill lamellae. Tips of the secondary gill lamellae had hyperplasia, hypertrophy and necrosis. Primary gill lamellae were hypertrophied, hemorrhagic and loss of pillar cells was also observed during this period (Table 2, Figure 1). In government farm, it was observed that in $C$. carpio both layer of skin were lost, dermis and myotomes were ruptured, thus vaculation were created in the month of November and December (Table 2, Figure 3).

On the other hand, pathological signs such as epidermis lost, dermis splitted into few parts, vacuoles and melanomacrophage $(\mathrm{mm})$ were noticed in the affected skin and muscle of $C$. carpio collected from NGO fish farm (Table 2, Figure 4). ${ }^{[7]}$ also made a similar observations that epidermis and dermis were sloughed off in most cases, and numerous protozoan cysts with full of spores were lying side by side underneath the scale fold in $C$. mrigala. [1] reported that epidermis and dermis were totally lost and necrotic muscle in A. testudineus during December and January.

Structures of liver were almost normal in C. carpio during April and May in both the farms. During the months of June, July and August haemorrhage, necrosis, pyknotic nuclei and vacuums were seen (Table 3, Figure 6). In November and December the liver showed ilets of lengerhans, vacuums, pyknotic nuclei, degenerated and necrotic hepatocytes (Table 2, Figure 5). According to ${ }^{[15]}$ hemorrhage and ruptured hepatocytes were seen in $N$. nandas and $P$. sophore in November and December. ${ }^{[14]}$ also made similar opinion that liver exhibited varying degrees of pathological changes including cytoplasmolysis, nuclear pyknosis and necrosis leading to complete degeneration of hepatocytes. However, in the present experiment less pathological changes such as pyknotic nuclei, and vacuums were found in the hepatocytes of fishes of NGO farm (Table 3).

Like other internal organs, kidney had normal structure during April and May in fish of both the farms. But from June to August, swollen kidney tubules, necrosis, haemorrhagic and ruptured haemopoietic tissues observed in kidney (Table 2). However, in October kidney tubles were necrotic having wide vaccums and pyknotic nuclei. Similar pathological symptoms of kidney of major carp were observed by other authors like ${ }^{[2,9]}$. From the above result we can mention here that $C$. carpio from both farms were severally affected during colder months.

Among the organs, gills were more affected than others organs in fish of both the farms from November and December. ${ }^{[3]}$ reported that external organs like gill and skin were more affected than internal organs such muscle, liver and kidneys of Channa punctatus and Nandus nandus. ${ }^{[2]}$ were found opposite result that histologically the internal organs like kidney and liver were more affected than external organs and disease like EUS occurred during the months of December and January.

From the clinical and histopathological point of view, the investigated fish species were normal in April and May. Less pathological changes were observed in June, July and August. On the other hand marked pathological changes were recorded in October and severities of pathological changes were gradually increased during November and December. ${ }^{[10,2,4]}$ found similar observations on EUS outbreaks in the Philippines, Bangladesh and Thailand respectively. From the experiment, clinically and histopathologically juvenile carp fishes of NGO fish farm were less affected compare to Government fish farm especially in colder moths of the year.

Most of the examined juvenile carps from different farms of Mymensingh area seemed to be healthy, but under clinical and histological observation it was found that a great percentage of fish were affected by different infectious agents. Again large percentage of fishes was affected specially during the cold period. So, proper preventive measure should be taken before out break of such diseases. From the management point of view, NGO fish farm seemed to be better than the Government fish farm where lower percentages of infestation were recorded. Thus it could be suggested that more precautionary measures would need to be carried out in the Government fish farm to prevent and control disease in order to save the species. Introduction of pathogens and infected fish to the water bodies from other sources should be prevented as far as possible. Steps should be taken to prevent the pollution and habitat destruction. However, more research works are essential in order to draw a final conclusion on the cause of disease outbreak in juvenile carps of nursery ponds in Bangladesh through histological techniques. 


\section{ACKNOWLEDGEMENTS}

We are grateful to United States Agency for International Development (USAID), Bangladesh and WorldFish Center-Bangladesh for their funding to establish a PCR laboratory for screening WSSV free shrimp seed in Bangladesh. We would also like to thank all the hatchery operators who support us in various aspects throughout the study period.

\section{REFERENCES}

1. Ahmed GU, Dhar M, Khan MNA, Choi JS. (2007). Investigation of diseases of Thai Koi, Anabas testudineus (BLOCH) from farming conditions in winter. Korean J. life Sci., 17(10):1309-1314.

2. Ahmed GU, Hoque MA (1999). Mycotic involvement in epizootic ulcerative syndrome of freshwater fishes of Bangladesh. A histopathological study. Asian Fish. Sci., Philippines. 12: 381-390.

3. Ahmed GU, Parveen R, Sultana S (2004). Disease investigation of small indigenous fishes from Kailla beel in Mymensingh area. J. Bangladesh Agril. Univ. 2 (2):305-311.

4. Chinabut S (1994). EUS in Thailand. ODA Regional Seminar on Epizootic Ulcerative Syndrome at Aquatic Animal Health Research Institute, Bangkok, Thailand. January 1994, pp. 58-60.

5. Chowdhury MBR (1993). Research priorities for microbial fish disease and its control in Bangladesh. In: Proceeding of the Workshop on Research Priorities of Bangladesh for fish health, disease prevention and pathology. May 17, Edited by Alan Tollervey, pp. 8-11.

6. Chowdhury MBR (1997). Bactterial involvement in fish disease in Bangladesh. Presented at the international symposium on Disease in Marine Aquaulture, October 3-6, 1997. Hiroshima, Japan. Abstract (iii): 2-24.
7. Hossian MS, Mazid MA (1995). A manual on development of floodplain fisheries. Fisheries Research Institute, Mymensingh. 2p (In Bengali).

8. Hossain MS, Paul SK (1993). Study of fish disease into the floodplains. In research progress report (June-September 1993). Fisheries Research Institute, Third Fisheries Project, Santahar, Bogra, October 1993. $46-52$.

9. Islam MJ, Ahmed GU, Islam T, Haque MA, Sarker MGA (1999). Gill pathology of carps disease from farming system of Bangladesh. Bangladesh J. Fish. 22 (2): 113-118.

10.Palisoc PP (1990). Philippines Report, In: Regional Research Program on relationship between epizootic ulcerative syndrome in Fish and the Environment. 13-25 August. NACA, Bangkok, Thailand, 45-417.

11.Plumb JA (1994). Health maintenance of cultured fishes, principal microbial diseases. CRC Press Boca Raton Ann Arbor, London, Tokyo. 42p.

12. Post DG (1987). Text Book of Fish Health. T. F. H. Publications, Inc. Ltd. 221 West Sylvania Avenue, Neptune City, NJ. 00753, USA. 6-10.

13. Rahman MM, Chowdhury MBR (1996). Isolation of bacterial pathogen causing on ulcer disease in farmed carp fishes of Mymensingh. Bangladesh. J. Fish. 19: 103-110.

14. Ram RN, Singh SK (1988). Carbofuran induced histopathological and biochemical changes in liver of the teleost fish, Channa punctatus (Bloch). Ecotox. Environ. Safety, 16(3): 194-201.

15.Roy MK, Ahmed GU, Akter S, Akter N (2006). Study of health condition of small indigenous freshwater fishes of Ailee beel Mymensingh. Progress. Agric. 17(1): 201-209.

16. Tangtrongpiros J (1985). The Situation of freshwater fish disease epidemic and sanitary in Thailand. Paper presented at the 14th Conference of the 0. 1. E. Regional Commission for Asia, the Far East and Oceania. Colombo, 29 July - 2 August 1985. 